\title{
Factors associated with elevated blood pressure or hypertension in Afro-Caribbean youth: a cross-sectional study
}

\author{
Trevor S Ferguson Corresp., ${ }^{1}$ ， Novie OM Younger-Coleman ${ }^{1}$ ， Marshall K Tulloch-Reid ${ }^{1}$ ， Nadia R Bennett ${ }^{1}$, \\ Amanda E Rousseau ${ }^{1}$ ， Jennifer M Knight-Madden ${ }^{1}$, Maureen E Samms-Vaughan ${ }^{2}$ ， Deanna E Ashley ${ }^{3}$, \\ Rainford J Wilks ${ }^{1}$ \\ ${ }^{1}$ Caribbean Institute for Health Research, University of the West Indies, Mona, Kingston, Jamaica \\ 2 Department of Child Health, University of the West Indies, Mona, Kingston, Jamaica \\ 3 School of Graduate Studies and Research, University of the West Indies, Mona, Kingston, Jamaica \\ Corresponding Author: Trevor S Ferguson \\ Email address: trevor.ferguson02@uwimona.edu.jm
}

Background: Although several studies have identified risk factors for high blood pressure (BP), data from Afro-Caribbean populations are limited. Additionally, less is known about how putative risk factors operate in young adults and how social factors influence the risk of high BP. In this study, we estimated the relative risk for elevated BP or hypertension (EBP/HTN), defined as BP $\geq 120 / 80 \mathrm{mmHg}$, among young adults with putative cardiovascular disease (CVD) risk factors in Jamaica and evaluated whether relative risks differed by sex.

Methods: Data from 898 young adults, 18-20 years old, were analysed. BP was measured with a mercury sphygmomanometer after participants had been seated for 5 minutes. Anthropometric measurements were obtained, and glucose, lipids and insulin measured from a fasting venous blood sample. Data on socioeconomic status (SES) were obtained via questionnaire. CVD risk factor status was defined using standard cut-points or the upper quintile of the distribution where the numbers meeting standard cut-points were small. Relative risks were estimated using odds ratios (OR) from logistic regression models.

Results: Prevalence of EBP/HTN was $30 \%$ among males and $13 \%$ among females $(p<0.001$ for sex difference). There was evidence for sex interaction in the relationship between EBP/HTN and some of risk factors (obesity and household possessions), therefore we report sex-specific analyses. In multivariable logistic regression models, factors independently associated with EBP/HTN among men were obesity (OR 8.48, 95\% Cl 2.64-27.2, p<0.001), and high glucose (OR 2.01, $\mathrm{Cl} 1.20-3.37, \mathrm{p}=0.008$ ), while high HOMA-IR did not achieve statistical significance (OR 2.08, $\mathrm{Cl}$ 0.94-4.58, $\mathrm{p}=0.069$ ). In similar models for women, high triglycerides (OR 1.98, $\mathrm{Cl}$ 1.03-3.81, $\mathrm{p}=0.040$ ) and high HOMA-IR (OR 2.07, $\mathrm{Cl} 1.03-4.12, \mathrm{p}=0.039$ ) was positively associated with EBP/HTN. Lower SES was also associated with higher odds for EBP/HTN (4.63, Cl 1.31-16.4, $\mathrm{p}=0.017$, for moderate vs. high household possessions; OR 2.61, $\mathrm{Cl}$ 0.70-9.77, $p=0.154$ for low vs. high household possessions). Alcohol consumption was associated with lower odds of EBP/HTN among females only; OR $0.41(\mathrm{Cl} 0.18-0.90, \mathrm{p}=0.026)$ for drinking $<1$ time per week vs. never drinkers, and OR $0.28(\mathrm{Cl} 0.11-0.76, p=0.012)$ for drinking $\geq 3$ times per week vs. never drinkers. Physical activity was inversely associated with EBP/HTN in both males and females. 
Conclusion: Factors associated with EBP/HTN among Jamaican young adults include obesity, high glucose and high triglycerides and high HOMA-IR, with some significant differences by sex. Among women lower SES was positively associated with EBP/HTN, while moderate alcohol consumption was associated lower odds of EBP/HTN. 
1 Factors associated with elevated blood pressure or

2 hypertension in Afro-Caribbean youth: a cross-sectional

3 study

5 Trevor S Ferguson ${ }^{1}$, Novie OM Younger-Coleman ${ }^{1}$, Marshall K Tulloch-Reid ${ }^{1}$, Nadia R. Bennett ${ }^{1}$

6 Amanda E. Rousseau ${ }^{1}$, Jennifer M Knight-Madden ${ }^{1}$, Maureen E Samms-Vaughan ${ }^{2}$, Deanna E

7 Ashley $^{3}$, Rainford J. Wilks ${ }^{1}$

8 Institutions: ${ }^{1}$ Caribbean Institute for Health Research, The University of the West Indies, Mona,

Kingston, Jamaica

${ }^{3}$ School of Graduate Studies and Research, The University of the West Indies, Mona,

Kingston, Jamaica

Corresponding author:

Dr. Trevor Ferguson

Epidemiology Research Unit, Caribbean Institute for Health Research, University of the West Indies, Mona, Kingston 7, Jamaica. 


\section{Abstract}

20 Background: Although several studies have identified risk factors for high blood pressure (BP),

21 data from Afro-Caribbean populations are limited. Additionally, less is known about how putative

22 risk factors operate in young adults and how social factors influence the risk of high BP. In this

23 study, we estimated the relative risk for elevated $\mathrm{BP}$ or hypertension $(\mathrm{EBP} / \mathrm{HTN})$, defined as $\mathrm{BP} \geq$

24 120/80 $\mathrm{mmHg}$, among young adults with putative cardiovascular disease (CVD) risk factors in

25 Jamaica and evaluated whether relative risks differed by sex.

26 Methods: Data from 898 young adults, 18-20 years old,were analysed. BP was measured with a

mercury sphygmomanometer after participants had been seated for 5 minutes. Anthropometric

measurements were obtained, and glucose, lipids and insulin measured from a fasting venous

blood sample. Data on socioeconomic status (SES) were obtained via questionnaire. CVD risk

factor status was defined using standard cut-points or the upper quintile of the distribution where

the numbers meeting standard cut-points were small. Relative risks were estimated using odds ratios (OR) from logistic regression models.

Results: Prevalence of EBP/HTN was 30\% among males and 13\% among females ( $\mathrm{p}<0.001$ for

sex difference). There was evidence for sex interaction in the relationship between EBP/HTN and

some of risk factors (obesity and household possessions), therefore we report sex-specific

analyses. In multivariable logistic regression models, factors independently associated with

EBP/HTN among men were obesity (OR 8.48, 95\%CI 2.64-27.2, $\mathrm{p}<0.001$ ), and high glucose

(OR 2.01, CI 1.20-3.37, $\mathrm{p}=0.008)$, while high HOMA-IR did not achieve statistical significance

(OR 2.08, CI 0.94-4.58, $\mathrm{p}=0.069)$. In similar models for women, high triglycerides (OR 1.98, CI

1.03-3.81, $\mathrm{p}=0.040)$ and high HOMA-IR (OR 2.07, CI 1.03-4.12, p=0.039) was positively 
$439.77, \mathrm{p}=0.154$ for low vs. high household possessions). Alcohol consumption was associated with 44 lower odds of EBP/HTN among females only; OR 0.41 (CI 0.18-0.90, p=0.026) for drinking $<1$

45 time per week vs. never drinkers, and OR 0.28 (CI $0.11-0.76, \mathrm{p}=0.012)$ for drinking $\geq 3$ times per

46 week vs. never drinkers. Physical activity was inversely associated with EBP/HTN in both males

47 and females.

48 Conclusion: Factors associated with EBP/HTN among Jamaican young adults include obesity,

49 high glucose and high triglycerides and high HOMA-IR, with some significant differences by

50 sex. Among women lower SES was positively associated with EBP/HTN, while moderate alcohol

51 consumption was associated lower odds of EBP/HTN.

52 Key words: elevated blood pressure; hypertension; prehypertension; cardiovascular disease risk

53 factors; young adults; Caribbean, Blacks, Jamaica, socioeconomic status 


\section{Introduction}

55 High blood pressure (BP) is the leading risk factor for the global burden of disease, accounting

56 for approximately 7\% of global disability adjusted life years (Lim et al. 2012). Recent studies

57 suggest that while the prevalence of hypertension is decreasing in high-income countries,

58 prevalence is increasing in low and middle-income countries, with the largest increase seen in

59 countries in sub-Saharan Africa (Mills et al. 2016; NCD Risk Factor Collaboration 2016). The

60 adverse effect of high BP, particularly increased risk of coronary heart disease and stroke, is

61 continuous and graded throughout the range of systolic blood pressure (SBP) and diastolic blood

62 pressure (DBP), down to levels of $115 \mathrm{mmHg}$ and $75 \mathrm{mmHg}$, respectively (Lewington et al.

63 2002). Additionally, it has been estimated that approximately 50\% of disease burden attributable

64 to high BP occurs at levels below the 140/90 mmHg cut-off point traditionally used to define

65 hypertension (Poulter et al. 2015). Recently the American College of Cariology and American

66 Heart Association (ACC/AHA) proposed new guidelines for the evaluation and management of

67 high $\mathrm{BP}$ (Whelton et al. 2017). In this guideline, normal $\mathrm{BP}$ is defined having $\mathrm{SBP}<120 \mathrm{mmHg}$

68 and DBP $<80 \mathrm{mmHg}$; elevated $\mathrm{BP}$ is defined as SBP of $120-129 \mathrm{mmHg}$ and $\mathrm{DBP}<80 \mathrm{mmHg}$;

69 and hypertension defined as $\mathrm{SBP} \geq 130 \mathrm{mmHg}$ or $\mathrm{DBP}>80 \mathrm{mmHg}$. However, most of the

70 available data on prevalence of hypertension have used the criteria from the Seventh Report of

71 the Joint National Committee on the Prevention, Detection, Evaluation and Treatment of High

72 Blood Pressure (JNC 7), where hypertension is defined as SBP $\geq 140 \mathrm{mmHg}$ or DBP $\geq 90 \mathrm{mmHg}$,

73 and SBP of 120-139 mmHg or DBP of 80-89 is classified as prehypertension (Chobanian et al.

74 2003). Studies reporting prevalence estimates for children or adolescents $<18$ years old often use

75 criteria from The Fourth Report on the Diagnosis, Evaluation, and Treatment of High Blood

76 Pressure in Children and Adolescents by the National High Blood Pressure Education Program 
77 (NHBPEP) (National High Blood Pressure Education Program Working Group on High Blood

78 Pressure in Children and Adolescents 2004).

79 Reported prevalence of hypertension, using JNC 7 or NHBPEP criteria, in adolescents and young

80 adults vary widely, with estimates generally ranging from about $2 \%$ among $15-34$ year-olds in

81 Italy up to 19\% among young adults 24-34 years old in the USA (Battistoni et al. 2015).

82 However, prehypertension appears to be common in adolescents and young adults, with

83 prevalence estimates ranging from $12 \%-45 \%$ in various studies from countries such as India,

84 Uganda, United States and Jamaica (Amma et al. 2015; Ferguson et al. 2011b; Kayima et al.

85 2015; Kini et al. 2016; Redwine \& Daniels 2012). Given that high BP in childhood has been

86 shown to track into adulthood (Bao et al. 1995; Chen \& Wang 2008), studies of high BP in youth

87 provide essential information to inform interventions that would reduce the adverse effects of

88 high BP on cardiovascular health.

89 The aetiology of hypertension is multi-factorial, with complex interactions between genetic,

90 environmental, behavioural and social factors (Lloyd-Jones \& Levy 2013; Poulter et al. 2015;

91 Victor 2015). Established risk factors for hypertension include increasing age, higher levels of

92 adiposity, high dietary sodium, high alcohol consumption, family history of hypertension and

93 lower socioeconomic status (Lloyd-Jones \& Levy 2013). Underlying mechanism include

94 activation of the sympathetic nervous system, disorders of the renin-angiotensin aldosterone

95 pathways, disorders of renal regulation of sodium balance, insulin resistance, inflammation,

96 arterial stiffness and foetal programming (Acelajado et al. 2013; Victor 2015).

97 Complications of hypertension vary with race/ethnicity and it is conceivable that the mechanisms

98 underlying both aetiology and complications could vary similarly (Jones \& Hall 2006; Lackland

99 2014). Additionally, less is known about how these factors operate in young African origin 
100 populations and how social factors, particularly in a developing country context, influence the 101 risk of high BP.

102 In Jamaica, the prevalence of hypertension (using the JNC 7 criteria) among persons 15-74 years 103 old was estimated at 20\% in 2001, and 25\% in 2008 (Ferguson et al. 2011a). The prevalence of 104 prehypertension was $30 \%$ in 2001 and $35 \%$ in 2008 , and was shown to be associated with other 105 cardiovascular disease (CVD) risk factors and high rates of progression to hypertension 106 (Ferguson et al. 2011a; Ferguson et al. 2010c; Ferguson et al. 2008). Among 15-19 year-old 107 youth, the prevalence of prehypertension in 2006 was 29\% (Ferguson et al. 2011b). More 108 recently, the Modeling the Epidemiological Transition Study reported prevalence of hypertension 109 among urban Jamaicans 25-45 years old, with prevalence estimates of $6.8 \%$ among men and $10 \%$ 110 among women (Cooper et al. 2015). This study also found that the prevalence of CVD risk 111 factors was not always consistent with that expected, with Jamaican women having lower 112 diabetes prevalence despite high obesity prevalence and South African men having higher 113 prevalence of hypertension despite lower adiposity (Dugas et al. 2017). Given the high burden of 114 hypertension and prehypertension in Jamaica, studies evaluating the relative contribution of 115 various risk factors would provide necessary information to direct public health interventions. 116 This paper therefore evaluates the association between putative risk factors and elevated BP or 117 hypertension (EBP/HTN), defined as BP $\geq 120 / 80 \mathrm{mmHg}$, among Afro-Caribbean youth.

118 Specifically, we aimed to estimate the relative risk for having EBP/HTN among participants with 119 putative CVD risk factors, and to evaluate whether there were significant sex differences in risk 120 factors for EBP/HTN. 
Data Sources

123 We conducted a cross-sectional analysis using data from the third follow up of the Jamaica 1986

124 Birth Cohort Study (Ferguson et al. 2010a; McCaw-Binns et al. 2011). This study is a

125 longitudinal study of persons, born in Jamaica in September and October of 1986, and who were

126 a part of the Jamaica Perinatal Mortality Survey (Ashley et al. 1988). Details on this cohort have

127 been previously published (Bennett et al. 2014; McCaw-Binns et al. 2011). For this analysis, we

128 used data from 409 males and 489 females, 18-20 years old, collected in the third follow up of

129 the cohort between March 2005 and February 2007. The study was approved by the University of

130 the West Indies / Faculty of Medical Sciences Ethics Committee. Participants provided written

131 informed consent prior to measurements being done.

\section{Measurements and Definitions}

133 All data collection and measurements were done by trained research nurses. We obtained data on

134 demographic characteristics, general health, medical history, behavioural health risk factors and

135 socioeconomic status via questionnaire. Additionally, we obtained anthropometric and BP

136 measurements and performed venepuncture for analysis of blood glucose, lipids, insulin and

137 creatinine. A timed urine sample was obtained for measurement of urinary albumin excretion.

BP was measured with a mercury sphygmomanometer after the participant had been seated for 5 minutes. BP measurement followed a standardized protocol developed for the International

were taken at 1-minute intervals, with the mean of the second and third measurements being used

142 for analysis. EBP/HTN was defined as $\mathrm{SBP} \geq 120 \mathrm{mmHg}$ or $\mathrm{DBP}$ of $\geq 80 \mathrm{mmHg}$, corresponding to

143 the prehypertension and hypertension categories of JNC 7 and the elevated BP and hypertension

144 categories of the 2017 ACC/AHA guidelines (Chobanian et al. 2003; Whelton et al. 2017). None

145 of the participants were on medication for elevated blood pressure at the time of assessment. 
146 Weight was measured using a portable digital scale, which was calibrated daily. Height was

147 measured using a portable stadiometer. Waist and hip circumference were measured using a non-

148 stretchable nylon tape measure. Body mass index (BMI) was calculated as weight in kilograms

149 divided by the square of height in metres and BMI categories defined using the World Health

150 Organization categories: underweight $\left(\mathrm{BMI}<18.5 \mathrm{~kg} / \mathrm{m}^{2}\right)$, normal weight (BMI $18.5-24.9$

$151 \mathrm{~kg} / \mathrm{m}^{2}$ ), overweight (BMI $\left.25.0-29.9 \mathrm{~kg} / \mathrm{m}^{2}\right)$, obese $\left(\right.$ BMI $\geq 30 \mathrm{~kg} / \mathrm{m}^{2}$ ) (World Health

152 Organization 1995). The normal weight category was used as the reference group. Central obesity

153 was defined as a waist circumference $\geq 80 \mathrm{~cm}$ for women and $\geq 94 \mathrm{~cm}$ for men as recommended

154 for African Origin populations in the 2009 Consensus Criteria for the Metabolic Syndrome

155 (Alberti et al. 2009). Waist-to-hip ratio was calculated by dividing waist circumference by hip

156 circumference. High waist-to-hip ratio was defined using cut-points recommended by Lean et al.

157 as $\geq 0.95$ for males and $\geq 0.80$ for females (Lean et al. 1995).

158 Venous blood was collected after an overnight fast of at least eight hours. Samples were analysed

159 using standard laboratory protocols for measurement of fasting glucose, lipids, fasting insulin and

160 serum creatinine. White blood cell count and high sensitivity C-reactive protein (hsCRP) were

161 measured as markers of inflammation.

162 Details of laboratory procedures have been previously published (Bennett et al. 2014; Ferguson et

163 al. 2010a; Rocke et al. 2015; Tulloch-Reid et al. 2010). In brief, glucose was measured using the

164 glucose oxidase method (Alcyon, Analyzer); total cholesterol, triglycerides, and high density

165 lipoprotein cholesterol (HDL) were measured directly using enzymatic methods (Abbot Spectrum

166 Analyzer), while low density lipoprotein cholesterol (LDL) was calculated using the Friedewald

167 equation (total cholesterol - HDL - [TG/2.18], with all concentrations given in mmol/L). Serum

168 creatinine was measured using Jaffe's reaction on the Alcyon 300 Chemistry Analyser (Abbott),

169 while fasting insulin was measured using a chemiluminescent immunoassay (IMMULITE, 
170 Diagnostic Products Corporation, Los Angeles, CA); hsCRP was measured using an IMMULITE

171 immunoassay (Siemens Medical Solution Diagnostics, Los Angeles, CA). Microalbumin was

172 measured from a timed urine specimen using a chemiluminescent immunoassay method using the

173 IMMULITE Immunoassay System (Siemens, Los Angeles, CA).

174 Elevated glucose $(\geq 5.6 \mathrm{mmol} / \mathrm{L})$, elevated triglycerides $(\geq 1.7 \mathrm{mmol} / \mathrm{L})$ and low levels of high

175 density lipoprotein cholesterol [HDL] $(<1.0 \mathrm{mmol} / \mathrm{L}$ for males and $<1.3 \mathrm{mmol} / \mathrm{L}$ for females $)$

176 were defined using the metabolic syndrome criteria (Alberti et al. 2009). High total cholesterol

$177(\geq 5.2 \mathrm{mmol} / \mathrm{L})$ and high levels of low density lipoprotein [LDL] cholesterol $(\geq 4.1 \mathrm{mmol} / \mathrm{L})$ were

178 defined using the National Cholesterol Education Program Adult Treatment Panel III (ATP III)

179 criteria (Expert Panel on Detection Evaluation and Treatment of High Blood Cholesterol in

180 Adults 2001). For analyses including glucose and triglycerides values in the upper quintile of the

181 distribution were defined as elevated, because the proportion of participants meeting the

182 metabolic syndrome cut-points was very small, thus resulting in too few participants for

183 multivariable analyses. High hsCRP was defined as $>3.0 \mathrm{mg} / \mathrm{L}$, with values $>10 \mathrm{mg} / \mathrm{L}$ set to

184 missing, as recommended by the American Heart Association and Centers for Disease Control

185 (Pearson et al. 2003). Insulin resistance was estimated using the Homeostasis Model Assessment

186 (HOMA-IR) equations (Matthews et al. 1985). Values for HOMA-IR were log transformed to

187 account for non-normal distribution. Elevated HOMA-IR was classified as being in the upper

188 quintile of the log-HOMA-IR. For this paper we chose to dichotomize these characteristics in

189 order to quantify the effect of being in an abnormal (high risk) category and facilitate the

190 tailoring of public health messages aimed at risk reduction. Urine albumin and creatinine levels

191 were used to calculate the albumin to creatinine ratio (ACR) and elevated urine albumin defined

192 as ACR $\geq 30 \mathrm{mg} / \mathrm{g}$ as recommended by the 2012 Kidney Disease Improving Global Outcomes 
193 (KDIGO) Guidelines (Kidney Disease: Improving Global Outcomes (KDIGO) CKD Work Group 194 2013).

195 Socioeconomic status was assessed using data collected using a locally developed questionnaire 196 on parental education and occupation, and number of household possessions. The specific 197 questionnaire items are included in the supplementary files available online. Data on education 198 was collected as the highest level of education attained by either parent or guardian and then categorized as: post-secondary, secondary, or less than secondary. In Jamaica, children are required to complete a mandatory 6 years of elementary school (Grades 1-6) and five years of high school (Grades 7-11 or first to fifth form), after which they graduate from high school. Children may spend an extra 2 years in sixth form (Grades 12 and 13) before going on to university or college. In this classification, post-secondary education includes persons who completed college or university and persons with vocational training obtained after completing high school. Secondary education indicates persons who completed high school (up to grade 11) and less than secondary includes persons who did not complete high school (i.e. high school education up to grade 10 or below). Occupational categories were defined using the occupation of the household head and coded using the Jamaica Standard Occupational Classification (JSOC)

209 (Statistical Institute of Jamaica 1995). For this report occupation categories were classified as

210 professionals or managers, office, service or trade workers, and semi-skilled or unskilled

211 workers. For household possessions, participants were asked to indicate whether they had items

212 from a list of 17 household possessions and given one point for each item. They were then

213 classified in three possession score categories based on the distribution of items: low (0-9 items), moderate (10-14 items), and high (15-17 items). The list of items included in the possession score

215 is shown Table S1 of the supplementary file. Cut-points for this classification was chosen based 216 on the finding that the majority of participants had $10-14$ items, so that the groups with $0-9$ items 
217 would represent the lower end of the distribution and 15-17 items the upper end of the

218 distribution.

219 Data on physical activity, smoking (cigarettes or marijuana) and alcohol consumption were also 220 collected via questionnaire. For smoking, participants were classified as current smokers or non221 smokers, while for alcohol consumption participants were classified as: 'never drank alcohol',

222 'rarely drinks alcohol' (<1 time per week), 'drinks alcohol 1-2 times per week', or 'drinks alcohol

$223 \geq 3$ times per week'. Physical activity was classified based on the time spent doing sports or

224 exercise during leisure time using a locally developed questionnaire. Questionnaire items

225 included questions on time spent doing active sports or other activities such as brisk walking,

226 jogging, lifting weights, dance classes, and workout at a gym. The specific questionnaire items

227 are included in the online supplementary files. Physical activity assessed using this questionnaire

228 was shown to be more strongly associated with measures of obesity than the International

229 Physical Activity Questionnaire (IPAQ) (Younger et al. 2007). Participants with no leisure time

230 physical activity were classified as low physical activity level, those with $<3.5$ hours per week as

231 moderate physical activity level and those with 3.5 hours or more per week as high physical

232 activity level.

233

234

235

236

237

238

239

240

\section{Sample size and Power}

Given that we had a fixed available sample size of 409 males and 489 females and that we performed sex-specific analyses, we estimated the maximum detectable odds ratio instead of sample size. These estimates were computed for males and females, separately, using the power twoproportions command available in Stata 14 (StataCorp. 2015c). We estimated the prevalence of the outcome variable (EBP/HTN), from the sample at $30 \%$ for males and $13 \%$ for females, and used these and the available sample size to compute the maximum detectable odds ratio for exposures, with proportion exposed ranging from 0.1 to 0.5 for power of $80 \%$ at the $5 \%$ 
241 significance level. For males, the given sample size of 409 had $80 \%$ power to detect odds ratio of

2421.84 if the proportion exposed was 0.5 and 2.13 if the proportion exposed was 0.2 . For females

243 the given sample size of 489 had $80 \%$ power to detect odds ratio of 2.02 if the proportion

244 exposed was 0.5 and 2.34 if the proportion exposed was 0.2 .

245 Statistical methods

246 We performed data analysis with Stata version 14.1 software (Stata Corp., College Station,

247 Texas). We obtained descriptive statistics (means and proportions) for outcome and explanatory

248 variables within and across sex and blood pressure categories. If data were highly skewed, we

249 reported the median and interquartile range instead of the mean and standard deviation.

250 Proportions were compared using the Pearson's chi-squared test or Fisher's exact tests, as

251 appropriate. Differences in means were compared using the unequal variance two sample t-test.

252 Differences in medians were compared using the non-parametric equality of median test available

253 in Stata (StataCorp. 2015a).

254 Logistic regression and two-way analysis of variance (ANOVA) models were used to determine

255 if there was evidence for sex interaction in the relationship between BP sure and some of the

256 explanatory variables. Results for analyses assessing interaction using the logistic regression

257 models are shown in Table S2 in the supplementary file. There was evidence for sex interaction in

258 the relationship between EBP/HTN and some of risk factors (obesity, central obesity and

259 household possessions), therefore we report sex-specific results for regression analyses.

260 We used multiple imputation by chained equations to account for missing data for some

261 explanatory variables. The proportion of complete cases, i.e. participants with no missing values

262 for any of the variables of interest, was $43 \%(n=384)$; The majority of incomplete cases $(30 \%$ of

263 participants) had only had one missing value; 14\% had two missing values, $7 \%$ had three missing

264 values and 7\% had more than three missing values. Details on the number of missing values for 
265 each variable are shown in Table S3 in the supplementary file. A comparison of the complete

266 cases vs. the incomplete cases revealed only minor differences. Participants with missing values

267 were more likely to have albuminuria, fewer household possessions, lower physical activity and

268 lower alcohol consumption, but had no statistically significant differences for any other

269 characteristics. Given the proportion of participants with at least one missing value and the

270 observed differences between complete and incomplete cases, multiple imputation was used to

271 improve the power of the study and reduce bias that may be seen in the complete case analysis

272 (Nguyen et al. 2017; White et al. 2011). A stacked multiple imputed data set, consisting of the

273 original dataset and 25 data sets with imputations for missing values, was created using Stata's

274 mi suite of commands (StataCorp. 2015b). We compared imputed variable values to the observed

275 values to ensure that the imputed values were plausible; these data are shown in Table S4.

276 Bivariate logistic regression was used to assess the association between EBP/HTN and individual

277 explanatory variables. These bivariate models were estimated using Stata's mi suite of commands

278 and estimates combined by the software using Rubin rules (Marshall et al. 2009; StataCorp.

279 2015b). For use in model selection, we extracted the first of the 25 imputed data sets and

280 performed regular binary logistic regression on the single-imputed data, as recommended by

281 Wood, White and Royston (Wood et al. 2008). We used the backwards stepwise regression

282 algorithm available in Stata to identify variables for inclusion in the final model. All variables

283 hypothesized to be associated with the outcome were included in the first multivariable model

284 and p-value $>0.2$ was used to remove variables from the model. We then used the Pearson and

285 Hosmer-Lemeshow tests for goodness-of-fit to assess the models. Finally, we used Akaike

286 information criterion (AIC) to determine whether to include or exclude specific variables from

287 the final models. Final multivariable models were then run on the multiple imputed data set with

28825 imputations, using Stata's mi suite of commands and estimates combined by the software 
289 using Rubin rules (Marshall et al. 2009; StataCorp. 2015b). To assess the potential impact of the

290 imputed values on the final conclusions we also re-ran the final models without imputations (i.e.

291 complete case analysis); these results are shown in Table S5 in the supplementary files.

\section{Results}

293 Summary statistics for demographic and biomedical measurements are shown in Table 1. Mean

294 age at the time of the study was 18.8 years $(\mathrm{SD}=0.61)$, with no sex difference. Compared to

295 females, males had higher mean weight, height, SBP, DBP, fasting glucose, triglycerides and

296 creatinine, while females had higher mean total cholesterol, LDL and HDL cholesterol. Females

297 also had higher median hsCRP, fasting insulin concentration and HOMA-IR. Comparisons of

298 participants' characteristics by BP categories are shown in Table S6 of the supplementary file.

299 Overall, participants with EBP/HTN tended to have higher mean values of CVD risk factors.

300 Proportions of participants with EBP/HTN and other CVD risk factors, expressed as categorical

301 variables, are shown is Table 2. Overall prevalence of EBP/HTN was $21 \%$ and was twice as high

302 in men compared to women $(30 \%$ vs. $13 \%, \mathrm{p}<0.001)$. The prevalence of elevated BP (SBP 120 -

$303129 \mathrm{mmHg}, \mathrm{DBP}<80 \mathrm{mmHg}$ ) was $9 \%$ (13\% among males and 5\% among females, $\mathrm{p}<0.001)$,

304 while hypertension ( $\mathrm{BP} \geq 130 / 80 \mathrm{mmHg}$ ) prevalence was $12 \%$ (17\% among males and $8 \%$ among

305 females, $\mathrm{p}<0.001)$. Prevalence of obesity was $8 \%$ (6\% among males and $10 \%$ among females,

$306 \mathrm{p}=0.008)$. The majority of participants were from middle-income households, with the household

307 head having completed secondary level education and working as office, service, or trade

308 workers. Low physical activity level was reported by $34 \%$ of participants and high physical

309 activity by $24 \%$. There were significant sex differences in physical activity among males

310 compared to females ( $p<0.001$ ) with $47 \%$ of females reporting low physical activity levels 
311 compared to $18 \%$ among males, while high physical activity was reported by $38 \%$ of males 312 compared to $13 \%$ among females. Cigarette smoking was reported by $14 \%$ of males and $6 \%$ of 313 females $(p<0.001)$, while $31 \%$ of males and $7 \%$ of females smoked marijuana $(p<0.001)$. Males

314 also reported higher levels of moderate ( $\geq 3$ times/week) alcohol consumption (38\% vs. 19\%, $315 \mathrm{p}<0.001)$. Similar analyses stratified by BP category are shown in Table S7 of the supplementary 316 file. Significant difference by blood pressure category were seen for BMI categories, central 317 obesity and waist-to-hip ratio among males, and for number of household possessions among 318 females.

319 The results from bivariate analyses yielding sex specific odds ratios for the relationship between 320 correlates and putative risk factors for elevated blood pressure are shown in Table 3. Factors 321 associated with elevated blood pressure among males in bivariate analyses were: age, obesity, 322 central obesity, high glucose, high triglycerides and high HOMA-IR. Among females, significant 323 correlates were age, height, high triglycerides, high HOMA-IR and number of household possessions. There were no significant associations for general or central obesity among females, and no significant associations for measures of inflammation (hsCRP and white blood cell count) or urine albumin excretion in either sex.

Results from the multivariable regression models are shown in Table 4. Models included

328 variables as shown in the table and were done separately for males and females. Modifiable risk 329 factors associated with higher odds of EBP/HTN among males were: obesity (OR 8.48, 95\%CI $3302.64-27.2, \mathrm{p}<0.001)$ and high glucose (OR 2.01, CI $1.20-3.37, \mathrm{p}=0.008)$. High HOMA-IR was 331 also associated with higher odds of EBP/HTN among males, but did not achieve statistical 332 significance (OR 2.08, CI 0.94-4.58, $\mathrm{p}=0.069)$. Among females, modifiable risk factors 333 associated with higher odds of EBP/HTN were: high triglycerides (OR 1.98, CI 1.03 - 3.81, 334 $\mathrm{p}=0.040)$, high HOMA-IR (OR 2.07, CI 1.03 - 4.12, p=0.039) and lower SES (OR 4.63, CI 1.31 - 
$33516.4, \mathrm{p}=0.017$ [moderate vs. high household possessions]. OR for low vs. high household

336 possessions was $2.61, \mathrm{CI} 0.70-9.77, \mathrm{p}=0.154$. The point estimates for obesity among females 337 suggested higher odds of EBP/HTN, but this was not statistically significant (OR 1.44 CI 0.58 $338-3.56, \mathrm{p}=0.436$ ). Additionally, age was positively associated with EBP/HTN in both sexes and 339 height in females only. Physical activity was inversely associated with EBP/HTN in both males 340 and females with OR of 0.49 (CI $0.24-0.97$ ) and 0.42 (CI $0.18-0.97$ ) for low vs high physical 341 activity level for males and females, respectively. Among women only, alcohol consumption was 342 inversely related to EBP/HTN Compared to those who never drank alcohol odds ratio for alcohol 343 consumption $<1$ time per week was 0.41 (CI $0.18-0.90, \mathrm{p}=0.026)$, while for those report alcohol 344 consumption $\geq 3$ times per week odds ratio were 0.28 (CI $0.11-0.76 p=0.012$ ). Findings for the complete case analysis with models from 306 males and 409 females (table S5 in supplementary file) were generally similar to that obtained with multiple imputation, however estimates have 347 wider confidence intervals and larger $p$-values, several of which did not achieve statistical 348 significance.

We also ran multivariable ANOVA models with SBP and DBP as the outcome variables, in order to assess the robustness of our findings, and whether using high BP cut-points for classification may have influenced our results. These models are shown in Tables S8A and S8B in the supplementary file. For the models with SBP as the outcome, the results for males were generally similar to the logistic regression model except that the association with physical activity level was no longer statistically significant and current cigarette smoking was now associated with higher odds of higher SBP. For females, obesity was now associated with higher systolic BP ( $\beta$ and the inverse association with alcohol consumption was now only significant only for the 358 'rarely drinks alcohol category'. For models with DBP as the outcome, the only metabolic risk 
359 factor showing a significant association was high triglycerides, which was inversely associated

360 among females only. Alcohol consumption was again inversely associated with DBP among

361 females and was positively associated with DBP among males. Physical activity was again

362 inversely associated with DBP among both males and females, but was statistically significant

363 only for low vs high physical activity among females. Current marijuana use was inversely

364 associated with DBP among males only.

365 An additional model with hypertension, defined using the 2017 ACC/AHA criteria, as the

366 outcome was also obtained and shown Table S9 in the supplementary file. Significant correlates

367 of hypertension in this model included high glucose among males and high triglycerides among 368 females.

\section{Discussion}

371 In this study, we have found that the prevalence of EBP/HTN among young adults in Jamaica is 372 higher among males compared to females and that there were significant sex differences in the

373 relationship between EBP/HTN and some of the risk factors explored. EBP/HTN was positively 374 associated with obesity and high glucose among males, and with high triglycerides, high HOMA-

375 IR and fewer household possessions among females. Higher levels of HOMA-IR was also

376 associated with EBP/HTN among males, but this did not achieve statistical significance. Physical

377 activity was inversely associated with EBP/HTN in both males and females, while alcohol

378 consumption was inversely associated with EBP/HTN in females only. The findings of this study

379 are generally consistent with the published literature, but there are noteworthy findings as

380 discussed below. 
381 The overall prevalence of EBP/HTN among young adults in this study was lower than that

382 reported for similar BP categories in a study from Uganda (Kayima et al. 2015), another in India

383 (Kini et al. 2016) and among young adults in the Bogalusa Heart Study (Toprak et al. 2009),

384 although the populations studied were generally older, with age ranging from 18-44 years.

385 Kayima and colleagues (Kayima et al. 2015) reported a prehypertension prevalence of $40 \%$ and

386 hypertension prevalence of $15 \%$ among young adults $18-40$ years old in Uganda, while Kini and

387 colleagues (Kini et al. 2016) reported of prehypertension prevalence of $45 \%$ and hypertension

388 prevalence of 3\% among persons 20-30 years old in the Udupi District in India. In the Bogalusa

389 Heart Study (Toprak et al. 2009), prehypertension prevalence was 37\% and hypertension

390 prevalence 13\% among persons 20-44 years old. Prevalence of combined prehypertension or

391 hypertension was also higher among indigenous youth in the USA (50\% among persons 14-39

392 years old) and in Australia (55\% among 15-24 year olds) (Drukteinis et al. 2007; Esler et al.

393 2016) Our prevalence estimates seem more aligned with the $12-17 \%$ prevalence of

394 prehypertension among adolescents (mainly from the United States) quoted by Redwine and

395 Daniels (Redwine \& Daniels 2012), but still lower than the 25\% prevalence reported by Amma

396 and colleagues (Amma et al. 2015) from Kerala in India. We also note that the prevalence of

$397 \mathrm{EBP} / \mathrm{HTN}$ in this study was also lower than the $29 \%$ prehypertension prevalence reported for

398 adolescents and young adults, 15-19 years old, from a national survey in Jamaica (Ferguson et al.

$3992011 \mathrm{~b}$ ) and the $31 \%$ prehypertension prevalence reported for adolescents and young adults 15-24

400 years old from a another national survey in Jamaica (Wilks et al. 2008). These findings suggest

401 the prevalence of elevated blood pressure may be lower among young adults in urban Jamaica,

402 and corroborates the finding of higher prevalence of hypertension among rural Jamaicans

403 previously reported (Ferguson et al. 2011a). The findings also support the recent reports for

404 higher prevalence of hypertension in Africa and Southeast Asia compared to the Americas (Mills

405 et al. 2016; NCD Risk Factor Collaboration 2016). 
406 The finding of higher prevalence of EBP/HTN among young males has been a consistent finding

407 for studies in Jamaica and elsewhere, including among indigenous youth in Australia and among

408 American Indians (Drukteinis et al. 2007; Esler et al. 2016; Ferguson et al. 2011b; Ferguson et al.

409 2008; Kayima et al. 2015; Kini et al. 2016; Toprak et al. 2009). The mechanisms underlying this

410 sex difference in EBP/HTN have not been clearly elucidated, however Maranon and Reckelhoff

411 suggested that both sex steroids and sex chromosomes effects, mediated by effects on the

412 sympathetic nervous system, renin angiotensin system and sodium reabsorption contribute to the

413 observed sex differences (Maranon \& Reckelhoff 2013). Joyner and colleagues suggested that

414 these sex differences may be mediated primarily through differences in $\beta$-adrenergic and $\alpha$ -

415 adrenergic mechanisms, which vary in relation to both age and sex (Joyner et al. 2016).

416 We also found that while EBP/HTN was related to obesity the relationship was much stronger in 417 males and, in fact, not statistically significant in females. We note that there were fewer females

418 with EBP/HTN, thus analyses for females had less power to show a statistically significant effect.

419 Additionally, when SBP was used as the outcome a statistically significant relationship was seen

420 for both sexes. The magnitude of the effect in males was however much larger in males, with an

421 almost six-fold increase in the relative risk compared to a mere $50 \%$ increase in females, and

422 regression coefficient in males being almost twice the value for females. The association between

423 increased weight and BP is well established and is thought to be mediated through sympathetic

424 nervous system activation, production of vasoactive adipocytokines and insulin resistance

425 (Acelajado et al. 2013; Lloyd-Jones \& Levy 2013). Our finding of a stronger effect of obesity on

426 BP among males compared to females is supported by the findings of Cutler and colleagues,

427 (Cutler et al. 2008) where the increase in hypertension prevalence between the National Health

428 and Nutrition Examination Survey (NHANES) 1988-1994 and NHANES 1999-2004 was almost

429 completely explained after adjusting for BMI in males but not in females. The reasons for the 
430 larger effect of obesity on BP in men compared to women is not fully understood, however one

431 study using 24-hour ambulatory BP monitoring found that average heart rate was higher in obese

432 compared to non-obese men while heart rates were similar in both obese and non-obese women

433 (Kagan et al. 2006). This suggest that sympathetic nervous system activation may be greater in

434 obese men versus obese women and could be a possible mechanism for the sex-differences in the

435 effect of obesity on BP. Our findings suggest that while reducing obesity is an important

436 component of any public health intervention to reduce the prevalence of hypertension, the effect

437 among women may be less than among men and therefore multi-component interventions may be

438 more appropriate.

439 Insulin resistance is now generally accepted as a causative factor in hypertension (Soleimani

440 2015; Zhou et al. 2014). Proposed mechanisms for hypertension in insulin resistance appear to be

441 related primarily to renal handling of sodium, and possibly to vasodilatory effects, vascular

442 smooth muscle cell proliferation and proinflammatory activity (Nakamura et al. ; Soleimani

443 2015; Zhou et al. 2014). Higher levels of HOMA-IR was associated with EBP/HTN among

444 females and borderline significant among males in this study. Additionally, high triglycerides was

445 associated with EBP/HTN among women. HOMA-IR, as well as fasting insulin and triglycerides,

446 are considered good surrogates measures on insulin resistance (Abbasi et al. 2014; Matthews et

447 al. 1985; McLaughlin et al. 2005). While we acknowledge that there are some limitations in the

448 use of HOMA in assessing insulin resistance (Thompson et al. 2014) as was done in this study, its

449 strong correlation with clinical measures of insulin resistance suggest that this is a useful method

450 for epidemiological studies (Thompson et al. 2014). Our findings suggest that insulin resistance

451 may be a potential target for preventing elevated BP. Potential approaches to reducing insulin

452 resistance include weight reduction, as well as targeting renal sodium handling or improving

453 insulin sensitivity (Soleimani 2015; Tsai et al. 2014). 
454 The association between lower socioeconomic status (based on number of household

455 possessions) and elevated BP among females in this study adds to the growing body of literature 456 on this subject. We have previously reported the lower maternal socioeconomic status (based on 457 maternal occupation) was related to systolic blood pressure in a previous paper from this cohort, 458 although in that report the effect was seen primarily among males (Ferguson et al. 2015). This sex 459 differential in the social determinants of chronic diseases has been a consistent feature in studies 460 from Jamaica (Ferguson et al. 2010a; Ferguson et al. 2010b; Mendez et al. 2003; Mendez et al. 461 2004) and suggests that sex differences must be considered when designing social interventions 462 in similar populations.

463 While high levels of alcohol consumption is associated with hypertension, several studies have 464 reported a J-shaped relationship, with light to moderate alcohol consumption being associated 465 with reduced BP, particularly among women (Cushman 2001; Di Castelnuovo et al. 2006; Fisher 466 et al. 2017; Fuchs et al. 1995; Sesso et al. 2008). Our finding of an inverse relationship between 467 alcohol consumption and $\mathrm{EBP} / \mathrm{HTN}$ among women is therefore consistent with the literature, if 468 we consider the highest drinking category of $\geq 3$ times/week as being consistent with moderate 469 alcohol consumption. Unfortunately, we did not have data on the actual quantity of alcohol 470 consumed and therefore were unable to explore this in the analysis.

471 The finding of lower odds of EBP/HTN among persons with lower physical activity was 472 unexpected as a large body of literature supports an association between higher physical activity 473 levels and lower BP (Diaz \& Shimbo 2013; Whelton et al. 2002). There are however a few 474 studies where high physical activity was found to be associated with higher BP (Teh et al. 2015;

475 Tsioufis et al. 2011). Possible explanations for these unexpected findings include 476 misclassification of physical activity level, particularly in studies where physical activity level is 477 based on self-report, residual confounding or a chance finding. Tsioufis and colleagues suggest 
478 that increased stroke volume and stimulation of mechanically sensitive muscle receptors could be

479 a possible explanation of their finding of higher BP among physically active adolescents in

480 Greece (Tsioufis et al. 2011). However, considering the large body of literature supporting the

481 inverse relationship between physical activity and BP, chance, bias or residual confounding seem

482 to be more plausible explanations.

483 This study had some limitations. Firstly, while the study had a moderately large sample size, the

484 number of females with EBP/HTN was relatively small and therefore would result in low power

485 to show statistically significant effects for some comparisons. Additionally, we did not have data

486 on salt intake, which is generally considered an important determinant of blood pressure. The

487 unavailability of data on quantity of alcohol consumed is also a limitation. We also acknowledge

488 that the data used in this analysis are somewhat dated and although we do not expect that the

489 biological effects of the putative risk factors would have changed since the data were collected, it

490 is possible that the distribution of risk factors may have changed and as such the magnitude of

491 some effects may also have changed. That a large proportion of participants had at least one

492 missing value for variables of interest was another limitation of this study. We were however able

493 to overcome this by using multiple imputation methods for bivariate and multivariable analyses.

494 Multiple imputation reduces the potential selection bias associated with complete case analysis

495 and also improves the power of the study by facilitating use of data from incomplete cases

496 (Nguyen et al. 2017; White et al. 2011). Finally, the cross-sectional design precludes us making

497 causal inferences from this study, however the risk factors studied have previously shown

498 associations in longitudinal studies, suggesting that these may be true determinants of elevated

499 blood pressure. Further studies with prospective evaluation of these risk factors in Afro-

500 Caribbean populations would provide stronger evidence for causal associations. 
501 Strengths of the study include the fact that we made detailed measurements of several CVD risk

502 factors in an Afro-Caribbean population, thus providing data that will help reduce the dearth of

503 data from the region. To our knowledge, this is the first study to evaluate effect of metabolic risk

504 factors such and insulin resistance and triglycerides on elevated BP among Afro-Caribbean youth.

505 The fact that we conducted sex specific analyses also allows for the exploration of separate

506 approaches to interventions targeted at men and women. This study may help in informing future

507 studies and in identifying potential targets for interventions aimed at reducing the adverse impact

508 of elevated blood pressure in Afro-Caribbean populations. Additionally, this study could provide

509 support for a public health policy targeting the reduction in metabolic risk factors in children and

510 young adults to reduce the future burden of hypertension and other cardiovascular diseases.

\section{Conclusions}

512 We have found that obesity, high glucose, high triglycerides and high HOMA-IR are correlates of

513 EBP/HTN among Afro-Caribbean young adults in Jamaica and that there are significant sex

514 differences in the relationship between some risk factors and EBP/HTN. Lower socioeconomic

515 status was also positively associated with EBP/HTN in females, while alcohol consumption was

516 inversely associated. These factors should be further explored in longitudinal studies, studies with

517 larger sample sizes or meta-analyses and should be considered when designing interventions to

518 ameliorate the adverse consequences of EBP/HTN. There is also a need for more mechanistic

519 studies to understand the aetiology of EBP/HTN in Black populations.

\section{Acknowledgements}

522 The authors acknowledge the contribution of the project staff (nurses, laboratory personnel,

523 administrative staff, and project assistants) for their contribution to the project.

\section{Author Contributions}


525 TSF - supervised field activities for data collection, developed data-analysis plan, lead the data 526 analysis, wrote first draft of manuscript and critically reviewed the manuscript

527 NOMYC - contributed to data collection, data analysis and critical review of the manuscript

528 MKTR - contributed to data collection, interpretation of data analyses and critical review of the 529 manuscript

530 NRB - contributed to interpretation of data; critically reviewed manuscript

531 AR - contributed to data checking and interpretation of data; critically reviewed manuscript

532 JKM - contributed to data collection, interpretation of data analyses and critical review of the 533 manuscript

534 MSV - contributed to the design of the study and critical review of the manuscript

535 DEA - contributed to the design of the study and critical review of the manuscript

536 RJW - conceived and designed the primary study and directed its implementation; contributed to 537 the data analysis strategies and data interpretation, critically reviewed drafts of the manuscript.

Abbasi F, Okeke Q, and Reaven GM. 2014. Evaluation of fasting plasma insulin concentration as an estimate of insulin action in nondiabetic individuals: comparison with the homeostasis model assessment of insulin resistance (HOMA-IR). Acta Diabetol 51:193-197. $10.1007 / \mathrm{s} 00592-013-0461-2$

Acelajado MC, Calhoun DA, and Oparil S. 2013. Pathogenesis of Hypertension. In: Black HR, WP, Loria CM, and Smith SC, Jr. 2009. Harmonizing the metabolic syndrome: a joint interim statement of the International Diabetes Federation Task Force on Epidemiology and Prevention; National Heart, Lung, and Blood Institute; American Heart Association; World Heart Federation; International Atherosclerosis Society; and International Association for the Study of Obesity. Circulation 120:1640-1645. 
553 Amma GM, Vasudevan B, and Akshayakumar S. 2015. Prevalence and determinants of

554

555

556

557

558

559

560

561

562

563

564

565

566

567

568

569

570

571

572

573

574

575

576

577 prehypertension and hypertension among adolescents: a school based study in a rural area of Kerala, India. Int J Res Med Sci 3:58-64. 10.5455/2320-6012.ijrms20150111

Ashley D, McCaw-Binns A, and Foster-Williams K. 1988. The perinatal morbidity and mortality survey of Jamaica 1986-1987. Paediatr Perinat Epidemiol 2:138-147.

Ataman SL, Cooper R, Rotimi C, McGee D, Osotimehin B, Kadiri S, Kingue S, Muna W, Fraser H, Forrester T, and Wilks R. 1996. Standardization of blood pressure measurement in an international comparative study. Journal of Clinical Epidemiology 49:869-877.

Bao W, Threefoot SA, Srinivasan SR, and Berenson GS. 1995. Essential hypertension predicted by tracking of elevated blood pressure from childhood to adulthood: the Bogalusa Heart Study. Am J Hypertens 8:657-665. 10.1016/0895-7061(95)00116-7

Battistoni A, Canichella F, Pignatelli G, Ferrucci A, Tocci G, and Volpe M. 2015. Hypertension in Young People: Epidemiology, Diagnostic Assessment and Therapeutic Approach. High Blood Press Cardiovasc Prev 22:381-388. 10.1007/s40292-015-0114-3

Bennett NR, Ferguson TS, Bennett FI, Tulloch-Reid MK, Younger-Coleman NOM, Jackson MD, Samms-Vaughan ME, and Wilks RJ. 2014. High sensitivity C-reactive protein is related to central obesity and the number of metabolic syndrome components in Jamaican young adults. Frontiers in Cardiovascular Medicine 1. 10.3389/fcvm.2014.00012

Chen X, and Wang Y. 2008. Tracking of Blood Pressure From Childhood to Adulthood: A Systematic Review and Meta-Regression Analysis. Circulation 117:3171-3180. 10.1161/circulationaha.107.730366

Chobanian AV, Bakris GL, Black HR, Cushman WC, Green LA, Izzo JL, Jr., Jones DW, Materson BJ, Oparil S, Wright JT, Jr., and Roccella EJ. 2003. The Seventh Report of the Joint National Committee on Prevention, Detection, Evaluation, and Treatment of High Blood Pressure: the JNC 7 report. JAMA 289:2560-2572. 
578 Cooper RS, Forrester TE, Plange-Rhule J, Bovet P, Lambert EV, Dugas LR, Cargill KE, Durazo-

579

580

581

582

583

584

585

586

587

588

589

590

591

592

593

594

595

596

597

598

599

600

601

Arvizu RA, Shoham DA, Tong L, Cao G, and Luke A. 2015. Elevated hypertension risk for African-origin populations in biracial societies: modeling the Epidemiologic

Transition Study. J Hypertens 33:473-480; discussion 480-471.

10.1097/hjh.0000000000000429

Cushman WC. 2001. Alcohol consumption and hypertension. J Clin Hypertens (Greenwich) 3:166-170.

Cutler JA, Sorlie PD, Wolz M, Thom T, Fields LE, and Roccella EJ. 2008. Trends in hypertension prevalence, awareness, treatment, and control rates in United States adults between 19881994 and 1999-2004. Hypertension 52:818-827. 10.1161/hypertensionaha.108.113357

Di Castelnuovo A, Costanzo S, Bagnardi V, Donati M, Iacoviello L, and de Gaetano G. 2006. Alcohol dosing and total mortality in men and women: An updated meta-analysis of 34 prospective studies. Arch Intern Med 166:2437-2445. 10.1001/archinte.166.22.2437

Diaz KM, and Shimbo D. 2013. Physical Activity and the Prevention of Hypertension. Curr Hypertens Rep 15:659-668. 10.1007/s11906-013-0386-8

Drukteinis JS, Roman MJ, Fabsitz RR, Lee ET, Best LG, Russell M, and Devereux RB. 2007. Cardiac and Systemic Hemodynamic Characteristics of Hypertension and Prehypertension in Adolescents and Young Adults. The Strong Heart Study 115:221-227. 10.1161/circulationaha.106.668921

Dugas LR, Forrester TE, Plange-Rhule J, Bovet P, Lambert EV, Durazo-Arvizu RA, Cao G, Cooper RS, Khatib R, Tonino L, Riesen W, Korte W, Kliethermes S, and Luke A. 2017. Cardiovascular risk status of Afro-origin populations across the spectrum of economic development: findings from the Modeling the Epidemiologic Transition Study. BMC Public Health 17:438. 10.1186/s12889-017-4318-4 
602 Esler D, Raulli A, Pratt R, and Fagan P. 2016. Hypertension: high prevalence and a positive

603

604

605

606

607

608

609

610

611

612

613

614

615

616

617 association with obesity among Aboriginal and Torres Strait Islander youth in far north Queensland. Aust N Z J Public Health 40 Suppl 1:S65-69. 10.1111/1753-6405.12401

Expert Panel on Detection Evaluation and Treatment of High Blood Cholesterol in Adults. 2001. Executive summary of the third report of the national cholesterol education program (ncep) expert panel on detection, evaluation, and treatment of high blood cholesterol in adults (adult treatment panel iii). JAMA 285:2486-2497. 10.1001/jama.285.19.2486

Ferguson TS, Francis DK, Tulloch-Reid MK, Younger NO, McFarlane SR, and Wilks RJ. $2011 \mathrm{a}$. An update on the burden of cardiovascular disease risk factors in Jamaica: findings from the Jamaica Health and Lifestyle Survey 2007-2008. The West Indian medical journal $60: 422-428$.

Ferguson TS, Tulloch-Reid MK, Younger NO, Knight-Madden JM, Samms-Vaughan M, Ashley D, Van den Broeck J, and Wilks RJ. 2010a. Prevalence of the metabolic syndrome and its components in relation to socioeconomic status among Jamaican young adults: a crosssectional study. BMC Public Health 10:307. 10.1186/1471-2458-10-307

Ferguson TS, Tulloch-Reid MK, Younger NO, McFarlane SR, Francis DK, and Wilks RJ. 2011 b. Prehypertension in Jamaica: a review of data from recent studies. West Indian Med J $60: 429-433$.

Ferguson TS, Younger-Coleman NO, Tulloch-Reid MK, Knight-Madden JM, Bennett NR, Samms-Vaughan M, Ashley D, McCaw-Binns A, Molaodi OR, Cruickshank JK, Harding S, and Wilks RJ. 2015. Birth weight and maternal socioeconomic circumstances were inversely related to systolic blood pressure among Afro-Caribbean young adults. Journal of Clinical Epidemiology 68:1002-1009. 10.1016/j.jclinepi.2015.01.026 
625 Ferguson TS, Younger N, Tulloch-Reid MK, Forrester TE, Cooper RS, Van den Broeck J, and

Wilks RJ. 2010b. Prevalence of the metabolic syndrome in Jamaican adults and its relationship to income and education levels. West Indian Med J 59:265-273.

Ferguson TS, Younger N, Tulloch-Reid MK, Lawrence-Wright MB, Forrester TE, Cooper RS, Van den Broeck J, and Wilks RJ. 2010c. Progression from prehypertension to hypertension in a Jamaican cohort: incident hypertension and its predictors. West Indian Med J 59:486-493.

Ferguson TS, Younger NO, Tulloch-Reid MK, Wright MB, Ward EM, Ashley DE, and Wilks RJ. 2008. Prevalence of prehypertension and its relationship to risk factors for cardiovascular disease in Jamaica: analysis from a cross-sectional survey. BMC Cardiovasc Disord 8:20. $10.1186 / 1471-2261-8-20$

Fisher NDL, Orav EJ, and Chang G. 2017. Effects of alcohol consumption on blood pressure in hypertensive women. Am J Drug Alcohol Abuse:1-6. 10.1080/00952990.2017.1355921

Fuchs CS, Stampfer MJ, Colditz GA, Giovannucci EL, Manson JE, Kawachi I, Hunter DJ, Hankinson SE, Hennekens CH, Rosner B, Speizer FE, and Willett WC. 1995. Alcohol Consumption and Mortality among Women. New England Journal of Medicine 332:12451250. 10.1056/nejm199505113321901

Jones DW, and Hall JE. 2006. Racial and Ethnic Differences in Blood Pressure. Biology and Sociology 114:2757-2759. 10.1161/circulationaha.106.668731

Joyner MJ, Wallin BG, and Charkoudian N. 2016. Sex differences and blood pressure regulation in humans. Exp Physiol 101:349-355. 10.1113/ep085146

Kagan A, Faibel H, Ben-Arie G, Granevitze Z, and Rapoport J. 2006. Gender differences in ambulatory blood pressure monitoring profile in obese, overweight and normal subjects. $J$ Hum Hypertens 21:128-134. 
649 Kayima J, Nankabirwa J, Sinabulya I, Nakibuuka J, Zhu X, Rahman M, Longenecker CT,

650

651

652

653

654

655

656

657

658

659

660

661

662

663

664

665

666

667

668

669

670

671

672

673

Katamba A, Mayanja-Kizza H, and Kamya MR. 2015. Determinants of hypertension in a young adult Ugandan population in epidemiological transition-the MEPI-CVD survey. BMC Public Health 15:830. 10.1186/s12889-015-2146-y

Kidney Disease: Improving Global Outcomes (KDIGO) CKD Work Group. 2013. KDIGO 2012 Clinical Practice Guideline for the Evaluation and Management of Chronic Kidney Disease. Chapter 1: Definition and classification of CKD. Kidney inter, Suppl 3:19-62.

Kini S, Kamath VG, Kulkarni MM, Kamath A, and Shivalli S. 2016. Pre-Hypertension among Young Adults (20-30 Years) in Coastal Villages of Udupi District in Southern India: An Alarming Scenario. PLoS One 11:e0154538. 10.1371/journal.pone.0154538

Lackland DT. 2014. Racial Differences in Hypertension: Implications for High Blood Pressure Management. Am J Med Sci 348:135-138. https://doi.org/10.1097/MAJ.0000000000000308

Lean ME, Han TS, and Morrison CE. 1995. Waist circumference as a measure for indicating need for weight management. BMJ : British Medical Journal 311:158-161.

Lewington S, Clarke R, Qizilbash N, Peto R, and Collins R. 2002. Age-specific relevance of usual blood pressure to vascular mortality: a meta-analysis of individual data for one million adults in 61 prospective studies. Lancet 360:1903-1913.

Lim SS, Vos T, Flaxman AD, Danaei G, Shibuya K, Adair-Rohani H, AlMazroa MA, Amann M, Anderson HR, Andrews KG, Aryee M, Atkinson C, Bacchus LJ, Bahalim AN, Balakrishnan K, Balmes J, Barker-Collo S, Baxter A, Bell ML, Blore JD, Blyth F, Bonner C, Borges G, Bourne R, Boussinesq M, Brauer M, Brooks P, Bruce NG, Brunekreef B, Bryan-Hancock C, Bucello C, Buchbinder R, Bull F, Burnett RT, Byers TE, Calabria B, Carapetis J, Carnahan E, Chafe Z, Charlson F, Chen H, Chen JS, Cheng AT-A, Child JC, Cohen A, Colson KE, Cowie BC, Darby S, Darling S, Davis A, Degenhardt L, Dentener 
674

675

676

677

678

679

680

681

682

683

684

685

686

687

688

689

690

691

692

693

694

695

696

697

698
F, Des Jarlais DC, Devries K, Dherani M, Ding EL, Dorsey ER, Driscoll T, Edmond K, Ali SE, Engell RE, Erwin PJ, Fahimi S, Falder G, Farzadfar F, Ferrari A, Finucane MM, Flaxman S, Fowkes FGR, Freedman G, Freeman MK, Gakidou E, Ghosh S, Giovannucci E, Gmel G, Graham K, Grainger R, Grant B, Gunnell D, Gutierrez HR, Hall W, Hoek HW, Hogan A, Hosgood HD, Hoy D, Hu H, Hubbell BJ, Hutchings SJ, Ibeanusi SE, Jacklyn GL, Jasrasaria R, Jonas JB, Kan H, Kanis JA, Kassebaum N, Kawakami N, Khang Y-H, Khatibzadeh S, Khoo J-P, Kok C, Laden F, Lalloo R, Lan Q, Lathlean T, Leasher JL, Leigh J, Li Y, Lin JK, Lipshultz SE, London S, Lozano R, Lu Y, Mak J, Malekzadeh R, Mallinger L, Marcenes W, March L, Marks R, Martin R, McGale P, McGrath J, Mehta S, Memish ZA, Mensah GA, Merriman TR, Micha R, Michaud C, Mishra V, Hanafiah KM, Mokdad AA, Morawska L, Mozaffarian D, Murphy T, Naghavi M, Neal B, Nelson PK, Nolla JM, Norman R, Olives C, Omer SB, Orchard J, Osborne R, Ostro B, Page A, Pandey KD, Parry CDH, Passmore E, Patra J, Pearce N, Pelizzari PM, Petzold M, Phillips MR, Pope D, Pope CA, Powles J, Rao M, Razavi H, Rehfuess EA, Rehm JT, Ritz B, Rivara FP, Roberts T, Robinson C, Rodriguez-Portales JA, Romieu I, Room R, Rosenfeld LC, Roy A, Rushton L, Salomon JA, Sampson U, Sanchez-Riera L, Sanman E, Sapkota A, Seedat S, Shi P, Shield K, Shivakoti R, Singh GM, Sleet DA, Smith E, Smith KR, Stapelberg NJC, Steenland K, Stöckl H, Stovner LJ, Straif K, Straney L, Thurston GD, Tran JH, Van Dingenen R, van Donkelaar A, Veerman JL, Vijayakumar L, Weintraub R, Weissman MM, White RA, Whiteford H, Wiersma ST, Wilkinson JD, Williams HC, Williams W, Wilson N, Woolf AD, Yip P, Zielinski JM, Lopez AD, Murray CJL, and Ezzati M. 2012. A comparative risk assessment of burden of disease and injury attributable to 67 risk factors and risk factor clusters in 21 regions, 1990-2010: a systematic analysis for the Global Burden of Disease Study 2010. The Lancet 380:22242260 . 
699 Lloyd-Jones DM, and Levy D. 2013. Epidemiology of Hypertension. In: Black HR, and Elliott

700

701

702

703

704

705

706

707

708

709

710

711

712

713

714

715

716

717

718

719

720

721

722

WJ, eds. Hypertension: A Companion to Braunwald's Heart Disease. Second Edition ed. Philadelphia: Elsevier, 1-11.

Maranon R, and Reckelhoff JF. 2013. Sex and gender differences in control of blood pressure. Clin Sci (Lond) 125:311-318. 10.1042/cs20130140

Marshall A, Altman DG, Holder RL, and Royston P. 2009. Combining estimates of interest in prognostic modelling studies after multiple imputation: current practice and guidelines. BMC Med Res Methodol 9:57. 10.1186/1471-2288-9-57

Matthews DR, Hosker JP, Rudenski AS, Naylor BA, Treacher DF, and Turner RC. 1985. Homeostasis model assessment: insulin resistance and beta-cell function from fasting plasma glucose and insulin concentrations in man. Diabetologia 28:412-419.

McCaw-Binns A, Ashley D, Samms-Vaughan M, Wilks R, Ferguson T, Younger N, Reece JA, Tulloch-Reid M, and Foster-Williams K. 2011. Cohort profile: the Jamaican 1986 birth cohort study. Int J Epidemiol 40:1469-1476. 10.1093/ije/dyq149

McLaughlin T, Reaven G, Abbasi F, Lamendola C, Saad M, Waters D, Simon J, and Krauss RM. 2005. Is There a Simple Way to Identify Insulin-Resistant Individuals at Increased Risk of Cardiovascular Disease? Am J Cardiol 96:399-404. http://dx.doi.org/10.1016/j.amjcard.2005.03.085

Mendez MA, Cooper R, Wilks R, Luke A, and Forrester T. 2003. Income, education, and blood pressure in adults in Jamaica, a middle-income developing country. IntJ Epidemiol $32: 400-408$.

Mendez MA, Cooper RS, Luke A, Wilks R, Bennett F, and Forrester T. 2004. Higher income is more strongly associated with obesity than with obesity-related metabolic disorders in Jamaican adults. IntJ ObesRelat Metab Disord 28:543-550. 
723 Mills KT, Bundy JD, Kelly TN, Reed JE, Kearney PM, Reynolds K, Chen J, and He J. 2016.

724 Global Disparities of Hypertension Prevalence and ControlClinical Perspective.

$725 \quad$ Circulation 134:441-450.

726 Nakamura M, Yamazaki O, Shirai A, Horita S, Satoh N, Suzuki M, Hamasaki Y, Noiri E, Kume

$727 \mathrm{H}$, Enomoto Y, Homma Y, and Seki G. Preserved Na/HCO3 cotransporter sensitivity to

728 insulin may promote hypertension in metabolic syndrome. Kidney Int 87:535-542.

$729 \quad 10.1038 / \mathrm{ki} .2014 .351$

730 National High Blood Pressure Education Program Working Group on High Blood Pressure in Children and Adolescents. 2004. The Fourth Report on the Diagnosis, Evaluation, and Treatment of High Blood Pressure in Children and Adolescents. Pediatrics 114:555-576.

NCD Risk Factor Collaboration. 2016. Worldwide trends in blood pressure from 1975 to 2015: a pooled analysis of 1479 population-based measurement studies with $19 \cdot 1$ million participants. The Lancet. 10.1016/S0140-6736(16)31919-5

Nguyen CD, Carlin JB, and Lee KJ. 2017. Model checking in multiple imputation: an overview and case study. Emerging Themes in Epidemiology 14:8. 10.1186/s12982-017-0062-6

Pearson TA, Mensah GA, Alexander RW, Anderson JL, Cannon RO, Criqui M, Fadl YY, Fortmann SP, Hong Y, Myers GL, Rifai N, Smith SC, Taubert K, Tracy RP, and Vinicor F.

744 Poulter NR, Prabhakaran D, and Caulfield M. 2015. Hypertension. Lancet 386:801-812. $10.1016 / \mathrm{s} 0140-6736(14) 61468-9$

Redwine KM, and Daniels SR. 2012. Pre-Hypertension in Adolescents: Risk and Progression. $J$ 
748 Rocke K, Ferguson T, Younger-Coleman N, Tulloch-Reid M, Knight-Madden J, Samms-Vaughan

$$
\text { M, Ashley D, McCaw-Binns A, and Wilks R. 2015. Relationship between Early Life }
$$

Factors and Renal Function in Afro-Caribbean Young Adults: Analysis from the Jamaica 1986 Birth Cohort Study. West Indian Med J. 10.7727/wimj.2015.450

Sesso HD, Cook NR, Buring JE, Manson JE, and Gaziano JM. 2008. Alcohol consumption and the risk of hypertension in women and men. Hypertension 51:1080-1087.

$$
\text { 10.1161/hypertensionaha.107.104968 }
$$

Soleimani M. 2015. Insulin resistance and hypertension: new insights. Kidney Int 87:497-499. 10.1038/ki.2014.392

StataCorp. 2015a. Stata Base Reference Manual Release 14. College Station, TX: StataCorp LLC.

StataCorp. 2015b. Stata Multiple Imputation Reference Manual Release 14. College Station, TX: StataCorp LLC.

StataCorp. 2015c. Stata Power and Sample-Size Reference Manual Release 14. College Station, TX: StataCorp LLC.

Statistical Institute of Jamaica. 1995. Jamaica Standard Occupational Classification 1991. Kingston, Jamaica.

Teh CH, Chan YY, Lim KH, Kee CC, Lim KK, Yeo PS, Azahadi O, Fadhli Y, Tahir A, Lee HL, and Nazni WA. 2015. Association of physical activity with blood pressure and blood glucose among Malaysian adults: a population-based study. BMC Public Health 15:1205. $10.1186 / \mathrm{s} 12889-015-2528-1$

Thompson D, Boyne M, Osmond C, Ferguson T, Tulloch-Reid M, Wilks R, Barnett A, and Forrester T. 2014. Limitations of fasting indices in the measurement of insulin sensitivity in Afro-Caribbean adults. BMC Research Notes 7:98. 
772 Toprak A, Wang H, Chen W, Paul T, Ruan L, Srinivasan S, and Berenson G. 2009.

773 Prehypertension and black-white contrasts in cardiovascular risk in young adults:

$774 \quad$ Bogalusa Heart Study. J Hypertens 27:243-250.

775 Tsai CM, Kuo HC, Hsu CN, Huang LT, and Tain YL. 2014. Metformin reduces asymmetric

776 dimethylarginine and prevents hypertension in spontaneously hypertensive rats. Transl

$777 \quad$ Res 164:452-459. 10.1016/j.trs1.2014.07.005

778 Tsioufis C, Kyvelou S, Tsiachris D, Tolis P, Hararis G, Koufakis N, Psaltopoulou T, Panagiotakos

779 D, Kokkinos P, and Stefanadis C. 2011. Relation between physical activity and blood

780 pressure levels in young Greek adolescents: the Leontio Lyceum Study. Eur J Public

$781 \quad$ Health 21:63-68. 10.1093/eurpub/ckq006

782 Tulloch-Reid MK, Ferguson TS, Younger NO, Van den Broeck J, Boyne MS, Knight-Madden

783 JM, Samms-Vaughan ME, Ashley DE, and Wilks RJ. 2010. Appropriate waist

784 circumference cut points for identifying insulin resistance in black youth: a cross sectional

785 analysis of the 1986 Jamaica birth cohort. Diabetol Metab Syndr 2:68. 10.1186/1758-

$786 \quad 5996-2-68$

787 Victor RG. 2015. Systemic Hypertension: Mechanisms and Diagnosis. In: Mann DL, Zipes DP,

788 Libby P, Bonow RO, and Braunwald E, eds. Braunwald's Heat Disease: A Textbook of

789 Cardiovascular Medicine. Tenth ed. Philadelphia: Elsevier, 934-952.

790 Whelton PK, Carey RM, Aronow WS, Casey DE, Collins KJ, Dennison Himmelfarb C, DePalma

791 SM, Gidding S, Jamerson KA, Jones DW, MacLaughlin EJ, Muntner P, Ovbiagele B,

792 Smith SC, Spencer CC, Stafford RS, Taler SJ, Thomas RJ, Williams KA, Williamson JD,

$793 \quad$ and Wright JT. 2017. 2017

794

ACC/AHA/AAPA/ABC/ACPM/AGS/APhA/ASH/ASPC/NMA/PCNA Guideline for the

795

Prevention, Detection, Evaluation, and Management of High Blood Pressure in Adults. $A$ 
796

797

798

799

800

801

802

803

804

805

806

807

808

809

810

811

812

813

814

815

816

817

Report of the American College of Cardiology/American Heart Association Task Force on Clinical Practice Guidelines. 10.1161/hyp.0000000000000065

Whelton SP, Chin A, Xin X, and He J. 2002. Effect of aerobic exercise on blood pressure: A meta-analysis of randomized, controlled trials. Ann Intern Med 136:493-503. 10.7326/0003-4819-136-7-200204020-00006

White IR, Royston P, and Wood AM. 2011. Multiple imputation using chained equations: Issues and guidance for practice. Stat Med 30:377-399. 10.1002/sim.4067

Wilks R, Younger N, Tulloch-Reid M, McFarlane S, and Francis D. 2008. Jamaica Health and Lifestyle Survey 2007-8. The University of the West Indies.

Wood AM, White IR, and Royston P. 2008. How should variable selection be performed with multiply imputed data? Stat Med 27:3227-3246. 10.1002/sim.3177

World Health Organization. 1995. Physical status: the use and interpretation of anthropometry. Report of a WHO Expert Committee. World Health Organ Tech Rep Ser 854:1-452.

Younger N, Ferguson T, Tulloch-Reid M, Knight-Madden J, Van den Broeck J, Jackson M, Bennett F, Samms-Vaughan M, Vaughan K, Ashley D, and R W. 2007. Estimating Physical Activity In Jamaica: Comparison Of The International Physical Activity Questionnaire (IPAQ) With A Locally Developed Questionnaire (LDQ). . Caribbean Health Research Council Scientific Meeting. Montego Bay, Jamaica: West Indian Med J. p 26.

Zhou M-S, Wang A, and Yu H. 2014. Link between insulin resistance and hypertension: What is the evidence from evolutionary biology? Diabetology \& Metabolic Syndrome 6:12. $10.1186 / 1758-5996-6-12$ 


\section{Table $\mathbf{1}$ (on next page)}

Mean or median values for participant characteristics and putative hypertension risk factors for males, females and both sexes

${ }^{*} \mathrm{p}<0.05 ;{ }^{* *} \mathrm{p}<0.01 ;{ }^{* * *} \mathrm{p}<0.001 \mathrm{SD}=$ standard deviation; $\mathrm{HDL}=$ high density lipoprotein;

$\mathrm{LDL}=$ low density lipoprotein; IQR = interquartile range (values correspond to the 25th and 75th centiles); hsCRP = high sensitivity C-reactive protein; HOMA-IR = Homeostasis Model Assessment - Insulin Resistance Differences in means were compared using the two-sample $t$ test with unequal variances, while the differences in medians were computed using the nonparametric equality-of-medians test. 
Table 1: Mean or median values for participant characteristics and putative hypertension risk factors for males, females and both sexes

\begin{tabular}{|c|c|c|c|}
\hline Characteristic & $\begin{array}{c}\text { Male } \\
\mathrm{n}=409 \\
\text { Mean } \pm \text { SD }\end{array}$ & $\begin{array}{c}\text { Female } \\
\mathrm{n}=489 \\
\text { Mean } \pm \mathrm{SD}\end{array}$ & $\begin{array}{c}\text { Both Sexes } \\
N=898 \\
\text { Mean } \pm \text { SD }\end{array}$ \\
\hline Age (years) & $18.8 \pm 0.59$ & $18.8 \pm 0.62$ & $18.8 \pm 0.61$ \\
\hline Weight $(\mathrm{kg}) * * *$ & $71.1 \pm 14.2$ & $62.4 \pm 15.5$ & $66.4 \pm 15.5$ \\
\hline Height $(\mathrm{cm}) * * *$ & $176.8 \pm 6.5$ & $163.6 \pm 6.1$ & $169.6 \pm 9.1$ \\
\hline Body mass index $\left(\mathrm{kg} / \mathrm{m}^{2}\right)$ & $22.7 \pm 4.3$ & $23.3 \pm 5.6$ & $23.0 \pm 5.0$ \\
\hline Systolic blood pressure $(\mathrm{mmHg})^{* * *}$ & $113.9 \pm 10.4$ & $107.4 \pm 8.8$ & $110.3 \pm 10.1$ \\
\hline Diastolic blood pressure $(\mathrm{mmHg}) * * *$ & $69.2 \pm 10.3$ & $66.9 \pm 9.2$ & $67.9 \pm 9.8$ \\
\hline Waist circumference $(\mathrm{cm})$ & $75.2 \pm 10.8$ & $73.9 \pm 12.1$ & $74.5 \pm 11.5$ \\
\hline Hip circumference $(\mathrm{cm})^{* *}$ & $94.4 \pm 8.9$ & $96.5 \pm 11.0$ & $95.5 \pm 10.2$ \\
\hline Waist-to-Hip ratio $* * *$ & $0.80 \pm 0.08$ & $0.77 \pm 0.14$ & $0.78 \pm 0.12$ \\
\hline White blood cell count (cells $\times 10^{9} / \mathrm{L}$ )*** & $5.3 \pm 1.6$ & $6.4 \pm 2.0$ & $5.9 \pm 1.9$ \\
\hline Fasting Glucose $(\mathrm{mmol} / \mathrm{L}) * * *$ & $4.7 \pm 0.6$ & $4.4 \pm 0.4$ & $4.6 \pm 0.5$ \\
\hline Total cholesterol $(\mathrm{mmol} / \mathrm{L}) * * *$ & $4.1 \pm 0.8$ & $4.5 \pm 0.9$ & $4.3 \pm 0.9$ \\
\hline HDL cholesterol $(\mathrm{mmol} / \mathrm{L}) * * *$ & $1.1 \pm 0.2$ & $1.2 \pm 0.3$ & $1.2(0.3)$ \\
\hline LDL cholesterol $(\mathrm{mmol} / \mathrm{L}) * * *$ & $2.7 \pm 0.7$ & $3.0 \pm 0.8$ & $2.9 \pm 0.8$ \\
\hline Triglycerides (mmol/L)* & $0.60 \pm 0.26$ & $0.56 \pm 0.26$ & $0.58 \pm 0.26$ \\
\hline \multirow[t]{2}{*}{ Creatinine $(\mu \mathrm{mol} / \mathrm{L})^{* * *}$} & $80.5 \pm 16.0$ & $56.9 \pm 25.5$ & $67.7 \pm 24.7$ \\
\hline & Median (IQR) & Median (IQR) & Median (IQR) \\
\hline Urinary albumin $(\mathrm{mg} / \mathrm{g}) *$ & $3.9(2.5,7.4)$ & $4.9(2.5,10.7)$ & $4.1(2.5,9.2)$ \\
\hline $\mathrm{hsCRP}(\mathrm{mg} / \mathrm{L}) * * *$ & $0.5(0.3,1.3)$ & $0.9(0.3,2.3)$ & $0.7(0.3,1.8)$ \\
\hline Fasting Insulin $(\mathrm{pmol} / \mathrm{L}) * * *$ & $4.4(2.7,7.1)$ & $6.8(4.1,10.1)$ & $5.8(3.3,8.8)$ \\
\hline \multicolumn{4}{|l|}{$* \mathrm{p}<0.05 ; * * \mathrm{p}<0.01 ; * * * \mathrm{p}<0.001$} \\
\hline \multicolumn{4}{|c|}{$\begin{array}{l}\mathrm{SD}=\text { standard deviation; HDL }=\text { high density lipoprotein; } \mathrm{LDL}=\text { low density lipoprotein; IQR }= \\
\text { interquartile range (values correspond to the } 25^{\text {th }} \text { and } 75^{\text {th }} \text { centiles); hsCRP }=\text { high sensitivity C- } \\
\text { reactive protein; HOMA-IR }=\text { Homeostasis Model Assessment }- \text { Insulin Resistance } \\
\text { Differences in means were compared using the two-sample t test with unequal variances, while } \\
\text { the differences in medians were computed using the nonparametric equality-of-medians test. }\end{array}$} \\
\hline
\end{tabular}




\section{Table 2 (on next page)}

Proportion of participants in categories for blood pressure and other CVD risk factors formales, females and both sexes

${ }^{*} \mathrm{p}<0.05 ;{ }^{* *} \mathrm{p}<0.01 ; * * * \mathrm{p}<0.001 \mathrm{BP}=$ blood pressure; $\mathrm{SBP}=$ systolic blood pressure; DBP = diastolic blood pressure; $C V D=$ cardiovascular disease ${ }^{1}$ Central obesity defined as waist circumference $\geq 94 \mathrm{~cm}$ in males and $\geq 80 \mathrm{~cm}$ in females ${ }^{2}$ High waist-to-hip ratio $\geq 0.95$ for males and $\geq 0.80$ for females ${ }^{~} E$ Education category "post-secondary" includes persons with vocational training, college, or university education; secondary corresponds to high school (up to grade 11); less than secondary corresponds to persons who had only elementary school education or persons who did not complete high school (i.e. high school grade 10 or below) 
Table 2: Proportion of participants in categories for blood pressure and other CVD risk factors for males, females and both sexes

\begin{tabular}{|c|c|c|c|}
\hline Characteristic & $\begin{array}{c}\text { Male } \\
\mathrm{n}=409 \\
\%(\mathrm{n})\end{array}$ & $\begin{array}{c}\text { Female } \\
\mathrm{n}=489 \\
\%(\mathrm{n})\end{array}$ & $\begin{array}{c}\text { Both Sexes } \\
\mathrm{N}=898 \\
\%(\mathrm{n})\end{array}$ \\
\hline Elevated $\mathrm{BP}$ or hypertension $(\mathrm{BP} \geq 120 / 80 \mathrm{mmHg})^{* * *}$ & $29.8(122)$ & $13.4(66)$ & $20.9(188)$ \\
\hline Elevated BP (SBP120-129 \& DBP <80 mmHg) $* * *$ & $13.2(54)$ & $5.3(26)$ & $8.9(80)$ \\
\hline Hypertension $(\mathrm{BP} \geq 130 / 80) * * *$ & $16.6(68)$ & $8.2(40)$ & $12.0(108)$ \\
\hline Stage 1 Hypertension (BP 130-139/80-89)*** & $14.7(60)$ & $7.4(36)$ & $10.7(96)$ \\
\hline Stage 2 Hypertension $(\mathrm{BP} \geq 140 / 90)$ & $2.0(8)$ & $0.8(4)$ & $1.3(12)$ \\
\hline Albuminuria & $5.1(20)$ & $8.3(39)$ & $6.8(59)$ \\
\hline \multicolumn{4}{|l|}{ Body mass index categories $* * *$} \\
\hline Underweight $\left(<18.5 \mathrm{~kg} / \mathrm{m}^{2}\right)$ & $6.1(25)$ & $14.5(71)$ & $10.7(96)$ \\
\hline Normal weight $\left(18.5-24.9 \mathrm{~kg} / \mathrm{m}^{2}\right)$ & $76.3(308)$ & $55.2(270)$ & $64.4(578)$ \\
\hline Overweight $\left(25-29.9 \mathrm{~kg} / \mathrm{m}^{2}\right)$ & $13.0(53)$ & $19.8(87)$ & $16.7(150)$ \\
\hline Obese $\left(\geq 30 \mathrm{~kg} / \mathrm{m}^{2}\right)$ & $5.6(23)$ & $10.4(51)$ & $8.2(74)$ \\
\hline Central obesity ${ }^{1 * * *}$ & $5.1(21)$ & $24.4(119)$ & $15.6(140)$ \\
\hline High waist-to-hip ratio ${ }^{2 * * *}$ & $1.0(4)$ & $20.3(99)$ & $11.5(103)$ \\
\hline \multicolumn{4}{|l|}{ Highest Education of Parent/Guardian ${ }^{3}$} \\
\hline Post-Secondary & $26.2(89)$ & $29.8(131)$ & $28.2(220)$ \\
\hline Secondary & $61.8(210)$ & $55.4(243)$ & $58.2(453)$ \\
\hline Less than Secondary & $12.1(41)$ & $14.8(65)$ & $13.6(106)$ \\
\hline \multicolumn{4}{|l|}{ Occupation of Household Head } \\
\hline Professionals/Managers & $23.5(88)$ & $24.7(114)$ & $24.1(202)$ \\
\hline Office, Service or Trade Workers & $49.3(185)$ & $50.9(235)$ & $50.2(420)$ \\
\hline Semi-Skilled/Unskilled Workers & $27.2(102)$ & $24.5(113)$ & $25.7(215)$ \\
\hline \multicolumn{4}{|l|}{ Number of Household Possession } \\
\hline High (15-17 items) & $\begin{array}{l}16.9 \\
(69)\end{array}$ & $13.7(67)$ & $15.2(136)$ \\
\hline Moderate (10-14 items) & $56.9(232)$ & $54.2(265)$ & $55.4(497)$ \\
\hline Low (0-9 items) & $26.2(107)$ & $32.1(157)$ & $29.4(264)$ \\
\hline \multicolumn{4}{|l|}{ Physical Activity Level*** } \\
\hline High & $37.5(153)$ & $13.1(64)$ & $24.2(217)$ \\
\hline Moderate & $44.4(181)$ & $39.5(193)$ & $41.7(374)$ \\
\hline Low & $18.1(74)$ & $47.4(232)$ & $34.1(306)$ \\
\hline Current Cigarette Smoking*** & $13.7(56)$ & $6.1(30)$ & $9.6(86)$ \\
\hline Current Marijuana Smoking*** & $31.3(127)$ & $7.2(35)$ & $18.1(162)$ \\
\hline \multicolumn{4}{|l|}{ Alcohol Consumption $* * *$} \\
\hline Never Drank Alcohol & $6.4(26)$ & $13.2(64)$ & $10.1(90)$ \\
\hline Rarely Drinks Alcohol & $26.4(107)$ & $45.2(219)$ & $36.6(326)$ \\
\hline Drinks Alcohol 1-2 times/week & $29.1(118)$ & $22.3(108)$ & $25.4(226)$ \\
\hline Drinks Alcohol $\geq 3$ times/week & $38.0(154)$ & $19.4(94)$ & $27.9(248)$ \\
\hline
\end{tabular}

$* \mathrm{p}<0.05 ; * * \mathrm{p}<0.01 ; * * * \mathrm{p}<0.001 ; \mathrm{BP}=$ blood pressure; SBP $=$ systolic blood pressure; DBP $=$ diastolic blood pressure; $\mathrm{CVD}=$ cardiovascular disease 
${ }^{1}$ Central obesity defined as waist circumference $\geq 94 \mathrm{~cm}$ in males and $\geq 80 \mathrm{~cm}$ in females ${ }^{2}$ High waist-to-hip ratio $\geq 0.95$ for males and $\geq 0.80$ for females

${ }^{3}$ Education category "post-secondary" includes persons with vocational training, college, or university education; secondary corresponds to high school (up to grade 11); less than secondary corresponds to persons who had only elementary school education or persons who did not complete high school (i.e. high school grade 10 or below) 


\section{Table 3 (on next page)}

Odds ratio for elevated blood pressure forfactors potentially associated with elevated blood pressure for male and femaleparticipants in the 1986 Jamaica Birth Cohort

${ }^{1}$ Central obesity defined as waist circumference $\geq 94 \mathrm{~cm}$ in males and $\geq 80 \mathrm{~cm}$ in females

${ }^{2} \mathrm{LDL}=$ low density lipoprotein cholesterol. Estimates for high LDL did not include imputed values, due to high correlation with high cholesterol leading to potential problems with perfect prediction in imputation models

${ }^{3} \mathrm{HDL}=$ high density lipoprotein; Low HDL defined as $<1.0 \mathrm{mmol} / \mathrm{L}$ for males and $<1.3 \mathrm{mmol} / \mathrm{L}$ for females

${ }^{4}$ HOMA-IR $=$ Homeostasis Model Assessment - Insulin Resistance

${ }^{5}$ hsCRP $=$ high sensitivity C-reactive protein; absolute value for odds ratio for males $=0.9998$

We did not compute odds ratios for elevated waist-to-hip ratio given the very small number of males $(n=4)$ with high waist to hip ratio 
Table 3: Odds ratio for elevated blood pressure for factors potentially associated with elevated blood pressure for male and female participants in the 1986 Jamaica Birth Cohort

\begin{tabular}{|c|c|c|c|c|c|c|}
\hline \multirow[b]{2}{*}{ Variable } & \multicolumn{3}{|c|}{$\begin{array}{c}\text { Males } \\
n=409\end{array}$} & \multicolumn{3}{|c|}{$\begin{array}{c}\text { Females } \\
n=489\end{array}$} \\
\hline & $\begin{array}{l}\text { Odds } \\
\text { Ratio } \\
\end{array}$ & $95 \% \mathrm{CI}$ & P-Value & $\begin{array}{l}\text { Odds } \\
\text { Ratio }\end{array}$ & $95 \% \mathrm{CI}$ & P-value \\
\hline Age (years) & 1.48 & $1.03-2.12$ & 0.034 & 2.16 & $1.41-3.31$ & $<0.001$ \\
\hline Height $(\mathrm{cm})$ & 1.02 & $0.98-1.05$ & 0.305 & 1.06 & $1.01-1.11$ & 0.009 \\
\hline \multicolumn{7}{|l|}{ BMI Category } \\
\hline Normal weight $\left(18.5-24.9 \mathrm{~kg} / \mathrm{m}^{2}\right)$ & 1.0 & - & - & 1.0 & - & - \\
\hline Underweight $\left(<18.5 \mathrm{~kg} / \mathrm{m}^{2}\right)$ & 0.52 & $0.17-1.58$ & 0.250 & 1.31 & $0.61-2.83$ & 0.489 \\
\hline Overweight $\left(25-29.9 \mathrm{~kg} / \mathrm{m}^{2}\right)$ & 1.54 & $0.83-2.85$ & 0.169 & 1.58 & $0.82-3.05$ & 0.172 \\
\hline Obese $\left(\geq 30 \mathrm{~kg} / \mathrm{m}^{2}\right)$ & 7.81 & $2.98-20.48$ & $<0.001$ & 1.95 & $0.89-4.29$ & 0.097 \\
\hline Central Obesity ${ }^{1}$ & 6.57 & $2.48-17.36$ & $<0.001$ & 1.54 & $0.88-2.72$ & 0.132 \\
\hline High Glucose (upper quintile) & 2.14 & $1.35-3.39$ & 0.001 & 1.20 & $0.48-3.01$ & 0.693 \\
\hline High Cholesterol $(\geq 5.2 \mathrm{mmol} / \mathrm{l})$ & 1.77 & $0.88-3.56$ & 0.110 & 1.62 & $0.88-2.97$ & 0.120 \\
\hline $\operatorname{High~LDL~}^{2}(\geq 4.1 \mathrm{mmol} / \mathrm{l})$ & 1.31 & $0.43-4.00$ & 0.634 & 1.25 & $0.53-2.94$ & 0.611 \\
\hline Low $\mathrm{HDL}^{3}$ & 1.11 & $0.67-1.83$ & 0.694 & 1.24 & $0.71-2.17$ & 0.449 \\
\hline High triglycerides (upper quintile) & 1.80 & $1.08-2.99$ & 0.024 & 1.96 & $1.10-3.51$ & 0.023 \\
\hline Creatinine $(\mu \mathrm{mol} / \mathrm{L})$ & 0.99 & $0.98-1.01$ & 0.421 & 1.00 & $0.99-1.01$ & 0.840 \\
\hline HOMA-IR ${ }^{4}$ (log, upper quintile) & 3.46 & $1.83-6.57$ & $<0.001$ & 1.81 & $1.01-3.26$ & 0.046 \\
\hline White blood cell count & 1.02 & $0.89-1.17$ & 0.781 & 1.12 & $0.99-1.27$ & 0.084 \\
\hline Albuminuria & 1.25 & $0.49-3.17$ & 0.641 & 1.14 & $0.46-2.82$ & 0.784 \\
\hline High hsCRP ${ }^{5}$ & 1.00 & $0.44-2.28$ & 1.000 & 1.51 & $0.79-2.88$ & 0.214 \\
\hline \multicolumn{7}{|l|}{ Parental Education } \\
\hline Post-Secondary & 1.0 & - & - & 1.0 & - & - \\
\hline Secondary & 0.92 & $0.54-1.59$ & 0.777 & 1.29 & $0.68-2.46$ & 0.433 \\
\hline Less than Secondary & 0.90 & $0.40-2.05$ & 0.800 & 1.22 & $0.52-2.89$ & 0.646 \\
\hline \multicolumn{7}{|l|}{ Occupation of Household Head } \\
\hline Professionals/Managers & 1.0 & - & - & 1.0 & & \\
\hline Office, Service or Trade & 0.74 & $0.43-1.28$ & 0.279 & 1.36 & $0.65-2.83$ & 0.416 \\
\hline Semi-Skilled/Unskilled & 0.89 & $0.48-1.63$ & 0.702 & 1.83 & $0.95-4.50$ & 0.067 \\
\hline \multicolumn{7}{|l|}{ No. of Household Possession } \\
\hline High (15-17 items) & 1.0 & - & - & 1.0 & - & - \\
\hline Moderate (10-14 items) & 0.58 & $0.33-1.02$ & 0.061 & 4.36 & $1.31-14.51$ & 0.016 \\
\hline Low $(0-9$ items $)$ & 0.81 & $0.43-1.53$ & 0.515 & 2.76 & $0.79-9.72$ & 0.113 \\
\hline \multicolumn{7}{|l|}{ Physical Activity Level } \\
\hline High & 1.0 & - & - & 1.0 & - & - \\
\hline Moderate & 0.83 & $0.52-1.32$ & 0.425 & 0.82 & $0.38-1.75$ & 0.605 \\
\hline Low & 0.71 & $0.38-1.32$ & 0.280 & 0.63 & $0.30-1.36$ & 0.243 \\
\hline
\end{tabular}




\begin{tabular}{lcccccc}
\hline & \multicolumn{3}{c}{$\begin{array}{c}\text { Males } \\
\mathbf{n = 4 0 9}\end{array}$} & & & \multicolumn{3}{c}{$\begin{array}{c}\text { Females } \\
\mathbf{n}=\mathbf{4 8 9}\end{array}$} \\
\hline Variable & $\begin{array}{c}\text { Odds } \\
\text { Ratio }\end{array}$ & $\mathbf{9 5 \%}$ CI & P-Value & $\begin{array}{c}\text { Odds } \\
\text { Ratio }\end{array}$ & 95\% CI & P-value \\
\hline Current Cigarette Smoking & 1.05 & $0.57-1.94$ & 0.879 & 0.99 & $0.33-2.92$ & 0.978 \\
Current Marijuana Smoking & 0.99 & $0.63-1.57$ & 0.991 & 0.82 & $0.28-2.39$ & 0.711 \\
Alcohol Consumption & & & & & & \\
$\quad$ Never Drank Alcohol & 1.0 & - & - & 1.0 & - & - \\
$\quad$ Rarely Drinks Alcohol & 1.01 & $0.39-2.67$ & 0.978 & 0.60 & $0.29-1.24$ & 0.166 \\
$\quad$ Drinks 1-2 times/week & 1.35 & $0.52-3.48$ & 0.534 & 0.58 & $0.26-1.34$ & 0.205 \\
$\quad$ Drinks $\geq 3$ times/week & 1.16 & $0.45-2.94$ & 0.762 & 0.47 & $0.19-1.14$ & 0.095 \\
\hline
\end{tabular}

${ }^{1}$ Central obesity defined as waist circumference $\geq 94 \mathrm{~cm}$ in males and $\geq 80 \mathrm{~cm}$ in females

${ }^{2} \mathrm{LDL}=$ low density lipoprotein cholesterol. Estimates for high LDL did not include imputed values, due to high correlation with high cholesterol leading to potential problems with perfect prediction in imputation models

${ }^{3} \mathrm{HDL}=$ high density lipoprotein; Low HDL defined as $<1.0 \mathrm{mmol} / \mathrm{L}$ for males and $<1.3 \mathrm{mmol} / \mathrm{L}$ for females

${ }^{4}$ HOMA-IR $=$ Homeostasis Model Assessment - Insulin Resistance

${ }^{5}$ hsCRP $=$ high sensitivity C-reactive protein; absolute value for odds ratio for males $=0.9998$

We did not compute odds ratios for elevated waist-to-hip ratio given the very small number of males $(n=4)$ with high waist to hip ratio 


\section{Table 4 (on next page)}

Factors Associated with ElevatedBlood Pressure or hypertension ( $B P \geq 120 / 80$ ) in Multivariable Logistic Regression Models among Male and Female Young Adults in the Jamaica 1986 BirthCohort

$\mathrm{BMI}=$ Body mass Index; HOMA-IR = Homeostasis Model Assessment Insulin Resistance; hsCRP = high sensitivity C-reactive protein.

Separate models created for males and females. Variables for inclusion in the final models were selected using backwards stepwise selection. Models for males included age, BMI category, high glucose, high HOMAIR, High hsCRP, possession category and physical activity levels. Models for females included age, height BMI category, high triglycerides, high HOMA-IR, possession category. physical activity levels and alcohol consumption categories. 
Table 4: Factors Associated with Elevated Blood Pressure or hypertension (BP $\geq 120 / 80$ ) in Multivariable Logistic Regression Models among Male and Female Young Adults in the Jamaica 1986 Birth Cohort

\begin{tabular}{|c|c|c|c|c|c|c|}
\hline \multirow[b]{2}{*}{ Variable } & \multicolumn{3}{|c|}{ Males $(n=409)$} & \multicolumn{3}{|c|}{ Females $(n=489)$} \\
\hline & $\begin{array}{l}\text { Odds } \\
\text { Ratio } \\
\end{array}$ & $95 \% \mathrm{CI}$ & $\begin{array}{c}\text { P- } \\
\text { Value } \\
\end{array}$ & $\begin{array}{l}\text { Odds } \\
\text { Ratio } \\
\end{array}$ & $95 \%$ CI & $\begin{array}{c}\text { P- } \\
\text { Value } \\
\end{array}$ \\
\hline Age (years) & 1.74 & $1.16-2.61$ & 0.007 & 2.55 & $1.60-4.08$ & $<0.001$ \\
\hline Height (cm) & - & - & - & 1.07 & $1.02-1.12$ & 0.003 \\
\hline \multicolumn{7}{|l|}{ BMI Category } \\
\hline Normal weight $\left(18.5-24.9 \mathrm{~kg} / \mathrm{m}^{2}\right)$ & 1.0 & - & - & 1.0 & - & - \\
\hline Underweight $\left(<18.5 \mathrm{~kg} / \mathrm{m}^{2}\right)$ & 0.64 & $0.20-2.00$ & 0.441 & 1.70 & $0.74-3.91$ & 0.211 \\
\hline Overweight $\left(25-29.9 \mathrm{~kg} / \mathrm{m}^{2}\right)$ & 1.76 & $0.90-3.43$ & 0.096 & 1.31 & $0.63-2.72$ & 0.461 \\
\hline Obese $\left(\geq 30 \mathrm{~kg} / \mathrm{m}^{2}\right)$ & 8.48 & $2.64-27.2$ & $<0.001$ & 1.44 & $0.58-3.56$ & 0.436 \\
\hline High Glucose (upper quintile) & 2.01 & $1.20-3.37$ & 0.008 & - & - & - \\
\hline High Triglycerides (upper quintile) & - & - & - & 1.98 & $1.03-3.81$ & 0.040 \\
\hline $\begin{array}{l}\text { HOMA-IR (log transformed, upper } \\
\text { quintile) }\end{array}$ & 2.08 & $0.94-4.58$ & 0.069 & 2.07 & $1.03-4.12$ & 0.039 \\
\hline High hsCRP & 0.45 & $0.17-1.17$ & 0.101 & - & - & - \\
\hline White blood cell count & - & - & & 1.14 & $0.99-1.31$ & 0.076 \\
\hline \multicolumn{7}{|l|}{ Household possessions } \\
\hline High (15-17 items) & 1.0 & - & - & 1.0 & - & - \\
\hline Moderate (10-14 items) & 0.62 & $0.33-1.18$ & 0.147 & 4.63 & $1.31-16.4$ & 0.017 \\
\hline Low (0-9 items) & 1.21 & $0.59-2.45$ & 0.604 & 2.61 & $0.70-9.77$ & 0.154 \\
\hline \multicolumn{7}{|l|}{ Physical Activity Level } \\
\hline High Physical Activity Level & 1.0 & - & - & 1.0 & - & - \\
\hline Moderate Physical Activity Level & 0.55 & $0.33-0.93$ & 0.026 & 0.71 & $0.31-1.65$ & 0.429 \\
\hline Low Physical Activity Level & 0.49 & $0.24-0.97$ & 0.042 & 0.42 & $0.18-0.97$ & 0.043 \\
\hline \multicolumn{7}{|l|}{ Alcohol Consumption } \\
\hline Never Drank Alcohol & - & - & - & 1.0 & - & - \\
\hline Rarely Drinks Alcohol (<once/week) & - & - & - & 0.41 & $0.18-0.90$ & 0.026 \\
\hline Drinks Alcohol 1-2 times/week & - & - & - & 0.46 & $0.19-1.15$ & 0.099 \\
\hline Drinks Alcohol $\geq 3$ times/week & & - & - & 0.28 & $0.11-0.76$ & 0.012 \\
\hline
\end{tabular}

BMI = Body mass Index; HOMA-IR = Homeostasis Model Assessment Insulin Resistance; hsCRP = high sensitivity C-reactive protein.

Separate models created for males and females. Variables for inclusion in the final models were selected using backwards stepwise selection. Models for males included age, BMI category, high glucose, high HOMA-IR, High hsCRP, possession category and physical activity levels. Models for females included age, height BMI category, high triglycerides, high HOMA-IR, possession category. physical activity levels and alcohol consumption categories. 
